\title{
Biomarkers for Early Cancer Detection - Methodological Aspects
}

\author{
Paolo Verderio $^{a} \quad$ Anita Mangia $^{b} \quad$ Chiara M. Ciniselli ${ }^{a}$ Paola Tagliabue $^{c} \quad$ Angelo Paradiso $^{d}$ \\ a Unit of Medical Statistics and Biometry, Fondazione IRCCS Istituto Nazionale dei Tumori, Milan, \\ ${ }^{\mathrm{b}}$ Clinical Experimental Oncology Laboratory, National Cancer Centr, Bari, \\ ${ }^{c}$ Department of Oncology, Azienda Ospedaliera Desio-Vimercate, Vimercate, \\ ${ }^{d}$ Scientific Direction, National Cancer Centre, Bari, Italy
}

\section{Key Words}

Biomarkers for early cancer detection - Breast cancer . Analytical validation - Clinical validation

\section{Summary}

The development of a new breast cancer biomarker for early detection is a process that begins with biomarker discovery, followed by a rigorous definition and evaluation of the whole process of biomarker determination (analytical validation). It terminates with the assessment of the impact of the biomarker on clinical practice (clinical validation). A 4-phase scheme for the analytical validation process of the biomarkers for early diagnosis has recently been proposed with the aim of covering the need for standardized operating procedures as well as the need for monitoring and maintaining their quality. As far as clinical validation of biomarkers for early diagnosis is concerned, however, a well established phased approach exists, and guidelines are available for both planning studies and reporting results. Although analytical and clinical validation should be logically linked, often this is not the case in real-word practice, especially in the early phases of biomarker development. This is also the case with breast cancer biomarkers for early detection.

\section{Introduction}

The need for a standardized process for biomarker validation in oncology has become increasingly relevant in the last years given the great number of promising biomarkers continuously

\section{Schlüsselwörter \\ Biomarker für die Früherkennung - Brustkrebs . Analytische Validierung · Klinische Validierung}

\section{Zusammenfassung}

Der Prozess der Entwicklung neuer Biomarker für die Brustkrebsfrüherkennung beginnt mit der Entdeckung des Biomarkers, gefolgt von einer strengen Definition und Bewertung des Gesamtprozesses der BiomarkerErmittlung (analytische Validierung). Der Vorgang endet mit der Einschätzung der Auswirkung des Biomarkers auf die klinische Praxis (klinische Validierung). Vor kurzem ist ein 4-Phasen-Schema für die analytische Validierung von Biomarkern für die Früherkennung vorgeschlagen worden, mit dem Ziel, den Bedarf an standardisierten Operating Procedures zu decken und deren Überwachung und langfristige Qualität zu gewährleisten. Für die klinische Validierung von Biomarkern für die Frühdiagnose existiert dagegen bereits ein etabliertes schrittweises Verfahren, und es sind Richtlinien für sowohl die Studienplanung als auch das Berichten von Ergebnissen vorhanden. Die analytische und die klinische Validierung sollten in logischer Folge miteinander gekoppelt sein, aber in der Praxis ist dies oft nicht der Fall, insbesondere in den frühen Phasen der Biomarkerentwicklung. Dies trifft auch auch die Biomarker für die Brustkrebsfrüherkennung zu. proposed in the literature. The development of a new cancer biomarker is a process that begins with biomarker discovery, followed by a rigorous definition and evaluation of the whole process of biomarker determination (analytical validation). It terminates with the assessment of the impact of the biomarker

\section{KARGER}

Fax +497614520714

Information@Karger.de

www.karger.com (c) 2010 S. Karger GmbH, Freiburg

www.karger.com/brc
Paolo Verderio, PhD

Unit of Medical Statistics and Biometry

Fondazione IRCCS Istituto Nazionale dei Tumori

Via Venezian, 1, 20133 Milan, Italy

Tel. +39 02 2390-3201, Fax -2095

paolo.verderio@istitutotumori.mi.it 
Table 1. Phases of biomarker analytical validation

\begin{tabular}{lll}
\hline Phase & Description \\
\hline I & $\begin{array}{l}\text { operating procedures }- \text { setting-up } \\
\text { operating procedures }- \text { standardization }\end{array}$ & $\begin{array}{l}\text { definition of operating procedures for biomarker determination } \\
\text { validation of the operating procedures in terms of precision and } \\
\text { accuracy according to the standards }\end{array}$ \\
II & internal quality control & $\begin{array}{l}\text { evaluation of the validated standards within laboratory } \\
\text { between laboratories }- \text { comparison and assessment of their accuracy }\end{array}$ \\
IV & external quality assessment &
\end{tabular}

Table 2. Phases of biomarker clinical validation

\begin{tabular}{|c|c|c|c|}
\hline Phase & & Objective & Study design \\
\hline $\mathrm{I}$ & preclinical exploratory & identify promising directions & case-control \\
\hline II & clinical assay and validation & determine if a clinical assay detects a specific disease & case-control (population-based) \\
\hline III & retrospective longitudinal & $\begin{array}{l}\text { verify if the biomarker is able to detect disease before it } \\
\text { becomes clinical }\end{array}$ & nested case-control in a population cohort \\
\hline IV & prospective screening & $\begin{array}{l}\text { determine extent and characteristics of disease detected } \\
\text { by the test }\end{array}$ & cross-sectional cohort of people \\
\hline $\mathrm{V}$ & cancer control & $\begin{array}{l}\text { impact of screening on reducing the burden of disease } \\
\text { on the population }\end{array}$ & randomized trial (ideally) \\
\hline
\end{tabular}

on clinical practice (clinical validation). The two latter steps are needed to confirm the usefulness of a novel biomarker as diagnostic tool, and they are logically linked so that the first one must precede any other kind of investigation moving to the clinical setting. This article will discuss some methodological aspects related to the identification of biomarkers for early Cancer detection.

\section{Analytical Validation of Biomarkers for Early Cancer Detection}

Analytical validation is the process of assessing the biomarker assay, its performance characteristics, and the optimal analytical setting to guarantee a satisfactory level of reproducibility and accuracy. The ultimate goal of this process should be reducing the number of promising biomarkers that fail in the clinical setting as a result of a lacking robust analytical validation. So far, a coherent and comprehensive set of guidelines for analytical validation of new biomarkers has not yet been delineated. A 4-phase scheme (table 1) has recently been proposed for the analytical validation process of biomarkers for early cancer diagnosis [1]. This scheme tries to cover the need for standardized operating procedures (SOPs) for the whole analytical process involved in early cancer biomarker determination as well as the need for monitoring and maintaining their quality. Both these needs have been recently stressed by some authors [2-5] as a prerequisite for clinical validation. In this context, assays for early cancer biomarkers should be analytically validated in external quality assurance (EQA) schemes before their effective implementation into routine laboratory testing in order to generate clinically useful information. EQA programs de- voted to directly evaluating the performance of biomarkers for early diagnosis have recently been proposed by different authors as an alternative approach to specific target-oriented EQA [6]. It should be considered that the reliability and validity of these cancer biomarkers are influenced by many factors, the impact of which may vary for different biomarkers in different types of specimens. For this reasons, it is crucial in EQA planning to have a thorough understanding of the assays employed by the participating laboratories in order to decide upon the most appropriate source material for challenge specimens. Another important aspect related to EQA implementation regards the choice of reference value that ideally should correspond to the true biomarker value. If a reference value is available, an EQA program can answer the question 'Can the results of a laboratory be deemed accurate?' On the other hand, in the absence of this value, an EQA program can only answer the more humble question 'May the results of a laboratory be deemed consistent with the majority (i.e. 95\%) of the results provided by all the participating laboratories?' For any EQA program based on cancer biomarkers, the latter is the most common situation. In this case, the most suitable reference value should be estimated by applying appropriate statistical procedures such as those based on parametric [7], robust [8], or distribution-free [9] approaches to data analysis.

\section{Clinical Validation of Biomarkers for Early Cancer Detection}

As far as clinical validation of biomarkers for early diagnosis is concerned, a well established multi-phased approach exists [10], with guidelines available for both planning studies [11] 
Table 3. Statistical guidelines for nested casecontrol studies

\begin{tabular}{ll}
\hline Item & Description \\
\hline 1 & $\begin{array}{l}\text { For the clearest interpretation, statistics should be based on false- and } \\
\text { true-positive rates, not odds ratios or relative risks. } \\
\text { To avoid overdiagnosis bias, cases should be diagnosed as a result of symptoms } \\
\text { rather than screening. } \\
\text { To minimize selection bias, the spectrum of control conditions should be the same } \\
\text { in study and target screening populations. } \\
\text { To extract additional information, criteria for a positive test should be based on } \\
\text { combinations of individual markers and changes in marker levels over time. } \\
\text { To avoid overfitting, the criteria for a positive marker combination developed in a } \\
\text { training sample should be evaluated in a random test sample from the same study and, } \\
\text { if possible, a validation sample from another study. } \\
\text { To identify biomarkers with true- and false-positive rates similar to mammography, } \\
\text { the training, test, and validation samples should each include at least 110 randomly } \\
\text { selected subjects without cancer and } 70 \text { subjects with cancer. }\end{array}$ \\
6
\end{tabular}

and reporting results [12]. In general, biomarker evaluation should follow an orderly multi-phased process (table 2) in which phase 1 studies are exploratory and often based on high throughput technology that produce high dimensional data for biomarker discovery. An important effect of the application of these 'omics' technologies on tissue samples and body fluids is the availability of complicated data in which the number of parameters, and thus the complexity of the model, is increasingly greater than the number of samples. As a consequence, the model fits the original data but fails when used to predict disease in an independent data set (overfitting). Two approaches are available to avoid this phenomenon of overfitting data: cross-validation and validation of independent datasets. Feng et al. [13] provided a detailed discussion on the most relevant statistical tools related to the use of highdimensional biomarkers for early detection. In phase 2 studies, biomarker values in cases (individuals with cancer) and controls (individuals without cancer) are directly compared. Phase 3 studies imply evaluation of the biomarker in a casecontrol study to assess its capability to detect sub-clinical disease. A phase 3 study should ideally be designed as a nested case-control study that involves prospective collection of specimens before outcome ascertainment from a study cohort that is relevant to the clinical application. An excellent guideline in statistical design and analysis of nested-case control study [14], available from the 4th report of the Early Detection Research Network (EDRN), is schematically shown in table 3. In a phase 4 study, the biomarker is detected prospectively as a screening test in a population. Finally, a phase 5 study consists essentially of a cancer screening study carried out to evaluate the utility of the biomarker as an indicator for early intervention. Baker et al. [15] reviewed key statistical methods applicable to each of the above-mentioned phases of biomarker clinical validation. Pepe et al. [10] have recently discussed how this original 5-phase approach could be slightly modified for situations in which preclinical specimens are available. Detailed description of the methodological issues
Table 4. Phases of development of breast cancer biomarkers for early detection

\begin{tabular}{lll}
\hline Biomarker & AV phase & CV phase \\
\hline Circulating nucleic acids & II & II \\
Methylation-based DNA in serum & I/II & I/II \\
High mobility group A proteins & I & I \\
$\mathrm{Na}^{+} / \mathrm{H}^{+}$exchanger regulatory factor 1 & I & I \\
\hline
\end{tabular}

$\mathrm{AV}=$ Analytical validation $\mathrm{CV}=$ clinical validation

related to each phase is beyond the scope of this note. The references provided should serve as a first step toward a more in-depth research to the interested reader.

\section{Conclusion}

Table 4 summarizes the development status of the different breast cancer biomarkers for early detection [16-19] according to the above-mentioned validation process. We consider as promising biomarkers those whose performance as a diagnostic tool should still be assessed or is being assessed. Interestingly, and by moving from a theoretical to a practical point of view, it seems that for all the biomarkers discussed in this issue, analytical and clinical validation proceed not as logically desirable. However, this trend is very common in cancer research, especially for potentially promising biomarkers the determination of which is based on the application of highly complex and quickly evolving technologies. The real-word validation process in such cases often consists of an overlap of the early phases of both validation processes. From this point of view, among the considered biomarkers, circulating nucleic acids appear to be the most developed, followed by methylation-based DNA biomarkers detected in serum. Specifically, as far as the analytical validation of circulating nucleic acids is 
concerned [16], different pre-analytical sources of variation have been described as related principally to the biological material (substrate) used for the assay and to the methods (inhouse or commercial kit) adopted for their purification. Overall, it seems that none of the different analytical approaches currently available can be used as standard until their validity within and between laboratory programs is not assessed. A direct consequence of this is the lack of prospective studies carried out to evaluate the clinical performance of circulating nucleic acids in detecting sub-clinical disease in asymptomatic subjects. Similar considerations seem to be compelling also for methylation-based DNA biomarkers [17]. Their development level appears to be appreciably slightly lower in comparison with the circulating nucleic acids as a result of poor assay performance (underperformance). Both analytical and clinical validation of most recent biomarkers based on the expression of high mobility group A proteins [18] and $\mathrm{Na}^{+} / \mathrm{H}^{+}$ exchanger regulatory factor expression [19] present a stimulating challenge in finding more effective interventions for the prevention and treatment of breast cancer. However, their analytical reliability is still influenced by many factors the impact of which should be more deeply investigated in order to develop shared operating procedures. This calls for a standardization of experimental protocols before clinically assessing the performance for classifying subjects into those with and without breast cancer.

\section{Acknowledgment}

This work was supported as a project of the Integrated Program of the Italian Ministry of Health: 'Analytical and clinical validation of biomarkers for non-invasive early diagnosis of female cancers'.

\section{Conflict of Interest}

The authors declare no conflict of interest.

\section{References}

1 Paradiso A, Mangia A, Orlando C, Verderio P, Belfiglio M, Marchetti A, Bertario L, Chiappetta G, Gion M, Tonini GP, Podo F, Vocaturo A, Silvestrini R, Romani M, Belloni E, Cavallo D, Ulivi P, Tommasi S, Steffan A, Russo A, Alessio M, Calistri D, Zancan M, Parrela P, Broggini M, Giuseppe A, Buttitta F, Finocchiaro G, Mazzocco K, Veronesi G, Landuzzi L, Benevolo M, Marian L, De Marco F, Venuti A, Giannelli G, Quaranta M, Trojano V: The Integrated Oncology Program of the Italian Ministry of Health. Analytical and clinical validation of new biomarkers for early diagnosis: network, resources, methodology, quality control, and data analysis. Int J Biol Markers 2009;24:119-29.

$\checkmark 2$ Tuck MK, Chan DW, Chia D, Godwin AK, Grizzle WE, Krueger KE, Rom W, Sanda M, Sorbara L, Stass S, Wang W, Brenner DE: Standard operating procedures for serum and plasma collection: early detection research network consensus statement standard operating procedure integration working group. J Proteome Res 2009;8:113-17.

3 Duffy MJ, Napieralski R, Martens JW, Span PN, Spyratos F, Sweep FC, Brunner N, Foekens JA, Schmitt M, EORTC PathoBiology Group: Methylated genes as new cancer biomarkers. Eur J Cancer 2009;45:335-46.

$\checkmark 4$ Apweiler R, Aslanidis C, Deufel T, Gerstner A Hansen J, Hochstrasser D, Kellner R, Kubicek M, Lottspeich F, Maser E, Mewes HW, Meyer HE, Müllner S, Mutter W, Neumaier M, Nollau P, Nothwang HG, Ponten F, Radbruch A, Reinert K, Rothe G, Stockinger H, Tarnok A, Taussig MJ, Thiel A, Thiery J, Ueffing M, Valet G, Vandekerckhove J, Verhuven W, Wagener C, Wagner O, Schmitz G: Approaching clinical proteomics: current state and future fields of application in fluid proteomics. Clin Chem Lab Med 2009;47:724-44.
5 Torlakovic EE, Naresh K, Kremer M, van der Walt J, Hyjek E, Porwit: A call for a European programme in external quality assurance for bone marrow immunohistochemistry; report of a European Bone Marrow Working Group pilot study. J Clin Pathol 2009;62:547-51.

6 Raggi CC, Pinzani P, Paradiso A, Pazzagli M, Orlando $\mathrm{C}$ : External quality assurance program for PCR amplification of genomic DNA: an Italian experience. Clin Chem 2003;49:782-91.

7 Verderio P, Dittadi R, Marubini E, Pizzamiglio S, Gion M, De Apollonia L, Paradiso A: Italian Network for Quality Assessment of Tumor Biomarkers (INQAT) Group. An Italian program of external quality control for chromogranin A ( $\mathrm{CgA})$ assay: performance evaluation of $\mathrm{CgA}$ determination. Clin Chem Lab Med 2007;45:1244-50.

8 Ramsden SC, Daly S, Geilenkeuser WJ, Duncan G, Hermitte F, Marubini E, Neumaier M, Orlando C, Palicka V, Paradiso A, Pazzagli M, Pizzamiglio S, Verderio P: EQUAL-quant: an international external quality assessment scheme for real-time PCR. Clin Chem 2006;52:1584-91.

-9 Orlando C, Verderio P, Maatman R, Danneberg J, Ramsden S, Neumaier M, Taruscio D, Falbo V, Jansen R, Casini-Raggi C, Malentacchi F, Marubini E, Pizzamiglio S, Vernelen K, Libeer JC, Palicka V, Pazzagli M: EQUAL-qual: a European program for external quality assessment of genomic DNA extraction and PCR amplification. Clin Chem 2007; 53:1349-57.

10 Pepe MS, Etzioni R, Feng Z, Potter JD, Thompson ML, Thornquist M, Winget M, Yasui Y: Phases of biomarker development for early detection of cancer. J Natl Cancer Inst 2001;93:1054-61.
11 Pepe MS, Feng Z, Janes H, Bossuyt PM, Potter JD: Pivotal evaluation of the accuracy of a biomarker used for classification or prediction: standards for study design. J Natl Cancer Inst 2008;100:1432-38.

12 Bossuyt PM, Reitsma JB, Bruns DE, Gatsonis CA, Glasziou PP, Irwig LM, Lijmer JG, Moher D, Rennie D, de Vet HC: Standards for reporting of diagnostic accuracy towards complete and accurate reporting of studies of diagnostic accuracy: the STARD initiative. BMJ 2003;326:41-4.

13 Feng Z, Prentice R, Srivastava S: Research issues and strategies for genomic and proteomic biomarker discovery and validation: a statistical perspective. Pharmacogenomics 2004;5:709-19.

14 Baker SG, Kramer BS, Srivastava S: Markers for early detection of cancer: statistical guidelines for nested case-control studies. BMC Med Res Methodol 2002;2:1-8.

15 Baker SG, Kramer BS, Mclntosh M, BH Patterson, Shyr Y, Skates S: Evaluating markers for the early detection of cancer: overview of study designs and methods. Clin Trials 2006;3:43-56.

16 Casciano I, Di Vinci A, Banelli B, Brigati C, Forlani A, Alemanni G, Romani M: Circulating tumor nucleic acids: perspective in breast cancer. Breast Care 2010;5 DOI: 10.1159/000310113.

17 Peluso S, Chiappetta G: High-mobility group A (HMGA) proteins and breast cancer. Breast Care 2010;5 DOI: $10.1159 / 000297717$.

18 Parrella P: Methylation based DNA markers in serum/plasma of breast cancer patients: a new promising tool for early detection. Breast Care 2010;5 DOI: 10.1159/000309138

19 Bellizzi A, Malfettone A, Cardone RA, Mangia A: NHERF1/EBP50 in breast cancer: clinical perspectives. Breast Care 2010;5 DOI: 10.1159/000298962. 